\title{
Implementation of Educational Parenting Patterns by Baduy People
}

\author{
Hasmika ${ }^{1}$, Elly Malihah ${ }^{2}$ \\ hasmika276@upi.edu \\ 1.2Universitas Pendidikan Indonesia
}

$\begin{array}{ccc}\text { Submitted } & \text { Revised } & \text { Accepted } \\ \text { May 16, 2020 } & \text { June 20, 2020 } & \text { June 21, 2020 } \\ & \text { https://dx.doi.org/ 10.17509/jpis.v29i1.24713 } & \end{array}$

\begin{abstract}
This study aims to describe the implementation of educational parenting patterns pf Baduy people, one of the indigenous people in Indonesia. The approach in this study is a qualitative approach administering documentation study or literacy to see or answer two problems in this study first, which is the implementation of parenting in education of the Baduy people. The results of this study showed that based on the historical facts, the Baduy tribe still upholds their customs in the interior of Banten Province in the Lebak Regency right in the Kanekes Village so that they cover themselves in formal education; however, for parenting in education, it turns out they still use customary methods in educating their children. The implementation of parenting in education was carried out in three ways, namely the implication of the adoption of parenting in education through the family environment, customary environment (Indigenous Leaders) and through peer learning.
\end{abstract}

Keywords: Parenting, Traditional Custom, Baduy Tribe Society

\begin{abstract}
ABSTRAK
Penelitian ini bertujuan untuk Mendeskripsikan Penerapan Pola Asuh Dalam Pendidikan Pada Masyarakat Suku Baduy, Pendekatan dalam penelitian ini adalah pendekatan kualitatif dengan analisis dengan study Dokumentasi atau literasi untuk melihat atau menjawab dua permasalahan dalam penelitian ini pertama Bagaimana sistem pola asuh dalam pendidikan Masyarakat Suku Baduy kedua bagaimana Penerapan Pola asuh dalam Pendidikan pada Masyarakat Suku Baduy. Hasil dari study literasi yang dilakukan maka mendapatkan hasil jawaban yakni Berdasarkan fakta sejarah bahwa suku Baduy masih menjunjung tinggi adat istiadatnya di pedalaman Provinsi Banten di Kabupaten Lebak tepat di Desa Kanekes sehingga mereka nutup diri dalam pendidikan formal, untuk pola pengasuhan dalam pendidikan Masyarakat Baduy sendiri mereka masih mengunakan cara-cara adat dalam mendidik anak-anak mereka. Penerapan pola asuh dalam pendidikan tersebut melalui tiga cara yakni Implikasi peneran pola asuh dalam pendidikan melalui lingkungan Keluarga, Impilakasi Penerapan Pola asuhnya Pada Lingkungan Adat (Tokoh Adat) dan Impilakasi Penerapan Pola asuhnya Pada Di dalam masyarakat Baduy belajar melalui teman sebaya.
\end{abstract}

Kata Kunci: Pola Asuh, Adat Istiadat, Masyarakat Suku Baduy

\section{PRELIMINARY}

Education is an essential thing in the process of humanity in a civilized society. In the current era of globalization, there is a tremendous change in human life which is inevitable from the tsunami of globalization that has entered every inch of modern 
human life. Education is a necessity for the development of Indonesian people because the basis for strategic development is education. Education must be used to educate all the people, not just for certain groups. Therefore, it is the state's duty to regulate this matter for the nation's intelligence process.

$$
\text { Scholte revealed that }
$$
globalization has become increasingly audible and its existence cannot be denied since the beginning of the 21st century Today we are faced with a time when all experienced rapid development and process changes that are interpreted as the era of globalization [1]. Globalization is a special phenomenon in human civilization that moves continuously in global society and is part of that global human process. The presence of information technology and communication technology accelerates the process of globalization.

Globalization touches all the important aspects of life. In line with that, Barker argues that globalization is a global economic, social, cultural and political connection that increasingly leads in various directions throughout the world and penetrates into our consciousness [2]. Besides that, Globalization creates various challenges and new problems that must be answered, solved in an effort to utilize globalization for the benefit of life. While Robertson explained that globalization refers to the narrowing of the world in incentives and increasing our awareness of the world, namely the increasing global connections and our understanding of these connections [3].

The process of narrowing the world can be understood in the context of the institution of modernity and intensification of world awareness can be perceived to be better reflexively culturally. In line with the presence of globalization, it certainly has an influence on the life of a country, including Indonesia, but besides that. Although modernization and globalization have influenced everything in society both culture and values, the role of interaction and communication that always occurs in humans will bring both processes into community life that will bring an impact of fast-paced change in order to face the life of a globally representative world who will also have an impact on the progress of the educational process.

Indigenous communities as part of Indonesian society are isolated from social groups, both physically, geographically and socially. Another definition is that the community has authenticity. It generally has historical continuity, peculiarities, marginalization, self-identity, and selfgovernment [4]. Most of these communities live in remote areas which are usually difficult to reach. Social institutions in this customary community generally rely on a very limited and homogeneous kinship relationship. Their daily lives are still based on traditional interactions that are biological in blood and marriage ties. One of the indigenous communities themselves is the Baduy tribe community.

The very interesting thing that the researchers want to examine is one of the Baduy tribes which is one of the very popular ethnic groups in Indonesia because of their obedience in maintaining the mandate of their ancestors. Ethnic groups spread across all regions in Indonesia generally have their own cultural systems. The cultural system includes beliefs, systems of values and norms, expressions of beauty, and ways of communication [5]. 
Basically, the Baduy community is a unique society [6]. The Baduy community is one of the tribes in Indonesia, which until now still maintains the basic cultural values they possess and believe in the midst of the advancement of civilization around them. Customs, culture, and traditions are still thick coloring the lives of Baduy people [7].

There are three main things that color their daily lives, namely a simple attitude to life, being friendly with natural nature, and the spirit of independence. Simple and simplicity are the points of fascination that are closely attached to the Baduy community. Until now the Baduy people are still trying to stay on their simplicity amid the strong currents of modernization in all aspects. For them simplicity is not lack or incapacity, but it becomes part of the meaning of happiness in real life [8].

Baduy is located in the village of Kanekes, Leuwidamar District, Rangkasbitung Regency, Banten. Baduy consists of Gajebo, Cikeusik, Cibeo, and Cikertawana Villages. Baduy people live in hilly, humid, and forested areas. The Baduy are divided into 2 groups, the Outer Baduy and the Inner Baduy. Each has a separate village. There are several things that underlie the formation of these 2 groups [9]. Territorially, which also determines the rules and habits of life, the Baduy are divided into two groups, the Inner Baduy and the Outer Baduy. [9].

Baduy Dalam consists of three villages namely Cibeo, Cikertawana, and Cikeusik. Characteristics of his clothing are natural white and dark blue and wear a white headband. They are traditionally prohibited from meeting with people who are not Indonesian citizens (foreign citizens), meanwhile, Outer Baduy are people who live in villages scattered around the Inner Baduy area. The names of the villages include Cikadu, Kaduketuk, Kadukolot, Gajeboh, Cisagu, and others. Outer Baduy are people who have come out of the traditional and territorial Baduy Dalam. Some characteristics of the Outer Baduy people, they are familiar with technology such as electronic equipment, although its use remains a prohibition for every Baduy, including Outer Baduy residents. In the construction of houses, they have used tools such as saws, hammers, nails, and others that are prohibited by the Baduy Dalam custom. Men wear traditional clothes in black or dark blue, which indicates that they are not pure. They sometimes use modern clothes such as T-shirts and jeans [9].

Simplicity in running life is a special attraction since the Baduy are an ethnic who deliberately alienate themselves from external influences (modernization) by choosing life by carrying out the mandate of their ancestors that we can see for ourselves when we visit their villages. The Baduy people consider themselves to be the inhabitants and maintainers of the earth's pancer or center of the world or the core of the universe. They lead a modest life by depending on life mainly from simple rice farming in the fields [10]. However, how long the Baduy can still maintain the mandate of the ancestors amidst the rapid needs, changes and developments of the era that cannot be avoided by the Baduy community is still questionable.

One interesting topic is the difference in the views of the Baduy community on education. The views of traditional leaders and the orientation of Baduy people about education are very diverse and have not yet led to a point of understanding whether formal 
education (schooling) for Baduy residents is a very taboo thing? Does the existence of formal education (schools) in Baduy will greatly harm and damage the future of Baduy residents? If schooling is taboo, why are there many among their citizens who are skilled at reading, writing and calculating so that they have the ability to communicate, interact, even have extensive business networks? If schooling is indeed prohibited, why among their active and creative citizens learning to read, write and count individually are not given sanctions? [11].

Based on historical facts that the Baduy still uphold their customs in the interior of the Banten Province in the Lebak Regency right in the Kanekes Village. People in Kanekes Village refer to themselves as Kanekes people, while many people know the inhabitants or tribes who are in the village as Baduy. All regulations are made together with the people to be obeyed together where the regulations are contained in the form of customs that are in harmony with their natural environment and life.

The process of separation was due to the violation of the customs so that the perpetrators will be excluded from the Baduy Area, which in the end they said was still considered part of the Baduy tribe but better known as outside Baduy. Of the two tribes, the same is certainly not independent of the process of interaction they live. However, the degree of dynamics of interaction that they experience is certainly different. In Baduy Dalam, which upholds the customs, it is impossible to find the use of technology in supporting their daily activities. They are also very careful when meeting with people other than Baduy.

Here we can perceive that Baduy in a very closed and difficult to accept the entry of other cultures into part of their culture, one of which is the formal education culture which until now has become one of the educators that the children of the nation are obliged to follow to enlighten the younger generation. But besides being baduy people close access to formal education patterns this is the reason researchers are interested in examining parenting in the Baduy community.

\section{LITERATURE REVIEW Parenting}

Parenting consists of two words: pattern, and foster. According Kamus Besar Bahasa Indonesia (KBBI) the Great Indonesian Dictionary, patterns are models, systems, or ways of working. In the meantime, fostering is maintaining, caring, educating, guiding, helping, training, and so on. Gunarsa stated that parenting is nothing but a method chosen by educators in educating their children which includes how educators treat their students [12]. This parenting is also a major factor in the formation of children [13].

It is safe to say that educators are parents, especially fathers and mothers or guardians. The involvement of parenting is an important activity for the welfare of the child [14]. Casmini said that parenting itself has a definition of how parents treat children, educate, guide, and discipline and protect children in reaching the process of maturity, to the efforts to establish norms expected by society in general [15]. On the other hand Thoha said that parenting is the best way parents can take in educating children as an embodiment of a sense of responsibility to children [16].

Meanwhile, according to Kohn, parenting is the attitude of parents in dealing with their children. This attitude 
can be seen from various aspects, including the way parents give arrangements to children, how to give gifts and punishments, how parents show authority and how parents pay attention, respond to children's desires [17]. Thus, what is meant by parenting is how to educate children both directly and indirectly. Based on the earlier description, it can be concluded that parenting is a process of interaction between parents and children, which includes activities such as nurturing, educating, guiding and disciplining in achieving maturity either directly or indirectly.

Besides that, parents have their own ways and patterns in caring for and guiding children. The ways and patterns will certainly differ from one family to another family [18]. Parenting is a picture of the attitudes and behavior of parents and children in interacting and communicating during parenting activities. Proper parenting can help parents apply positive values to children.

There are three types of parenting that are often applied by parents to children, namely parenting authoritarian parenting is parenting that emphasizes obedience and control, parenting permissive parenting is parenting that emphasizes selfexpression and self-regulation, and parenting Authoritative parents are parenting that combines respect for the individuality of children with efforts to instill social value [19].

\section{Customs}

Human efforts in the framework of fulfilling their needs certainly depend on their own ability to make nature an object that can be managed to meet their needs. So it can be said that the culture was born actually caused by human desire to meet their needs, in the form of behavior, lifestyle, economy, agriculture, kinship systems, social stratification, religion, myths and so on. All these aspects must then be fulfilled by humans in their lives which at the same time spontaneously will give birth to culture or traditions which are often also called customs.

Etymologically, adat comes from Arabic which means habit. Thus, customs can be etymologically defined as an act that is carried out repeatedly and then become a habit that is permanent and respected by people, then the habit becomes customary.

Adat has been institutionalized in community life in the form of traditions, customs, ceremonies, etc. that is able to control people's behavior in the form of feelings of pleasure or pride, and the role of traditional leaders who become community leaders becomes quite important. Customs or habits can be interpreted as the behavior of someone who is continually carried out in a certain way and followed by outside communities for a long time. Thus the elements of the creation of adat are the existence of a person's behavior, carried out continuously, the time dimension, and followed by other people I communities.

Understanding the customs and traditions concerning attitudes and behavior of people who are followed by other people in a process that is long enough, this shows the breadth of understanding of these customs. Each society or nation and state has its own customs, which are different from one another. Customs can reflect the soul of a society or nation and are a personality of a community or nation. The level of civilization, the modern way of life of a person cannot eliminate the behavior or 
customs that live and are rooted in society.

Adat always adapts itself to the conditions and progress of the times, so that adat remains eternal, because adat always adapts to the progress of society and the will of the times. Customs that live in the community are closely related to the traditions of the people and this is the main source of customary law:

The shah argues that adat is a traditional social rule that is sacred, meaning that it is an ancestral provision and has been adhered to for generations [20]. It is a tradition that regulates the indigenous people of Indonesia that is felt by its members to be very binding. As social norms that are considered sacred, the implementation of adat should be carried out based on customary norms that apply in each region without regard to stratification in people's lives.

Customs have strong ties and influence in society. The binding power depends on the community (or, part of the community) that supports these customs which mainly stem from feelings.

Besides that, custom is a complex of norms by individuals who hold it upheld in life. This custom, although considered permanent, will change over a long period of time [21].

From the explanation above, we can conclude Customs is a social habit that has long existed in society with the intention of regulating order. There are also those that bind norms and behavior in the community, so that in doing an action they will think about the impact of the results or the group of behavior that has the highest position because it is eternal and very strong integrated to the community that has it.

\section{Baduy Tribe Society}

Urang Baduy - Baduy people - is a group of Sundanese people, who reside in the administrative area of Lebak Regency, West Java Province (now the Baduy Area belongs to Banten Province). The village where he lives, Kanakes Village is located about $60 \mathrm{Km}$ south of Rangkasblitung City, the capital of Lebak Regency, while the shortest road to the villages of Baduy is the begunung area because their village road is a footpath. Kanakes Village, only inhabited by Urang Baduy or Baduy people. In Kanakes village there are no other ethnic groups of Indonesia, so the Baduy community members in the village are Homogeneous communities.

Baduy people divide themselves into two big groups namely the Tangtu or Baduy groups in (three kampongs) and the Panamping or Outer Baduy groups there are about 26 villages in Kanakes Village, which are now more numerous. The area of the village is $5 \mathrm{HA}$ with a population of 4,574 people, or 1.65 heads of households (kk) who inhabit 1,075 houses. Baduy people are distinguished from other Sundanese people who seem to have been able to defend their system of culture and culture from the changes that have continually affected their territory. [22]. But besides being based on historical facts that the Baduy still uphold their customs in the interior of Banten Province in the Lebak Regency right in the Kanekes Village.

People living in Desa Kanekes call themselves Kanekes people, while many people know the inhabitants or tribes who are in the village as Baduy. The name Baduy was originally brought by Dutch researchers who saw the behavior of Kanekes who lived nomadic (migrated), then likened to Badawi Arabs who behaved the same and 
Based on other historical records that the Baduy were remnants of the Pajajaran kingdom who had escaped due to war. They occupy a place that was once a forest under the leadership of a tribal leader (Jaro).

All regulations are made together with the people to be obeyed together where the regulations are contained in the form of customs that are in harmony with their natural environment and life. In the next development, the Baduy tribe will be divided into two big groups namely Inner Baduy and Outer Baduy. The process of separation was due to the violation of the customs so that the perpetrators will be excluded from the Baduy Area, which in the end they said was still considered part of the Baduy tribe but better known as outside Baduy.

Of the two tribes, the same is certainly not independent of the process of interaction they live. However, the degree of dynamics of interaction that they experience is certainly different. In Baduy Dalam, which upholds the customs, it is impossible to find the use of technology in supporting their daily activities. They are also very careful when meeting with people other than Baduy. Here we can perceive that Baduy in a very closed and difficult to accept the entry of other cultures into part of their culture. While other large groups known as Outer Baduy have tended to be open so that their interactions are dynamic.

Furthermore, Kurnia and Ahmad Sihabudin stated that the Baduy people's daily behavior is more directed towards the characteristics of life-style, that is, simple living as it is, limiting matters relating to the fulfillment of worldly needs or excessive material, living by referring to the burdens and norms. rules that are full of advice and meaning [11]. So from the description above, it can be concluded that the Baduy community is a community that lives a group of Sundanese people, who live in the administrative area of Lebak Regency, where the name of the village is Kanekas, which is generally only inhabited by Baduy people themselves, but in addition we often meet or hear Baduy names or terms are no stranger.

When this name is mentioned, the people immediately say that Baduy is the name of a tribe which for the people outside Baduy still consider them to be a primitive, backward, oldfashioned, traditional, rejecting modernity, or other similar terms. So it becomes very interesting to find out how the Baduy form their foster patterns in order to maintain the ancestral values that they always uphold.

\section{RESEARCH METHODS}

The approach in this study is a qualitative approach which is a study aimed at describing and analyzing, the phenomenon of events, social activities, attitudes, beliefs, perceptions, thoughts of individuals individually or in groups [23]. In addition, qualitative research is considered as a naturalistic study. This research departs from the naturalitic paradigm, that 'reality is plural in dimension, the researcher under study is interactive, inseparable, a unity is formed simultaneously and reciprocally, it is impossible to separate cause from effect and this research involves values' and methods that used in this study are Documents / Text.

According to Mudjia Raharjo, where the Document / Text study is part of the study that focuses on the analysis or interpretation of written materials based on the context, the material can 
be published notes, textbooks, newspapers, magazines, film letters, and diaries, manuscripts, articles and the like [24]. In connection with that, Bungin Burhan argued that the Document / Text study consisted of autobiology, correspondence, clippings or even data stored on the web site. [25]. In connection with the explanation above, this study uses document studies to obtain information about how the Implementation of Parenting in Education in the Baduy Community.

\section{RESULTS AND DISCUSSION Results}

Banten Province has traditional communities that still uphold their ancestors' traditions, namely the Baduy Ethnics who live in Kanékés Village, Leuwidamar District, Lebak Regency. The Baduy community in general is located in the Ciujung watershed in the Kendeng Mountains - South Banten. It is located about $172 \mathrm{~km}$ west of the capital city of Jakarta; about $65 \mathrm{~km}$ south of the capital city of Banten Province. Ethnic Baduy is divided into two parts, namely Inner Baduy and Outer Baduy. Baduy Dalam resides in three villages namely Cikeusik, Cikartawarna, and Cibeo, while Outer Baduy lives in villages outside the three villages, with a total of 62 villages [26].

In general, Baduy people are divided into three groups, namely tangtu (predecessor, forerunner, principal); panamping (edge, exhaust); and jackfruit (frame, dirty). Tangtu and Panamping are in the Kanekes village area, while the dangka is outside the Kanekes village. When viewed from the level of adherence to adat, then the tangtu is higher than panamping, and panamping is higher than jackfruit. The results of this study, the analysis used in this study is the analysis of the study documentation or literacy to see or answer the two problems in this study first How is the parenting system in education of the Baduy Tribe Society second how is the Implementation of Parenting in Education in the Baduy Tribe Society.

The results of the analysis carried out from several literacy questions answer the first problem, namely the parenting system in the education of the Baduy Tribe, emphasizing that Menutut Jaro Sami who is the representative of the adat leader (Puun) has the view that "Education in the Baduy Tribe is inheriting education indigenous knowledge ". It can be understood from this opinion that in the Baduy community, the most important and most important education for them is education about traditional knowledge. Traditional / traditional knowledge is a form of knowledge that cannot be obtained in formal education.

The education system run by the Baduy community is an education system that is adjusted to the customary orders which are the main foundation of the education system in the Baduy community. Based on observations in the field and interviews with several Baduy Dalam people, they expressed that until now, especially the Cibeo community, no one had attended formal education, they still used adat methods to educate their children. The following is the statement of Ayah Aldi as a resident of the Cibeo village: "That for indigenous peoples it is not permitted to participate in formal education which is permitted only for family and traditional education. Jaro Sami, as Puun's representative, is responsible for managing traditional education ". Can be explained indeed for their own education they are still 
limited to the family and customary environment.

M.J Langeveld, as quoted by Kartini Kartono, stated that Education is an effort to grow and develop physical and spiritual potential in accordance with the values that exist in society and culture. Education is an information delivery event that takes place in a situation of communication between people to achieve the desired goals. So that in essence education is all human efforts to defend their civilization by instilling the values, norms, culture passed down to the next generation. The Baduy Society In view of this education, they believe that traditional education with different models / forms of education in general is the best way for its civilization. Then how is their response to formal education (school) is it really taboo?

The following is the statement of the Baduy Dalam people towards formal education: "Formal school is absolutely not allowed from customary rules, I don't know the reason but the rules have been there from the past, from the time of my grandfather to my father." (Interview of Ayah Aldi, Cibeo) "Formal education is prohibited, the reason is I don't know, if the word parents cannot mean that they must not follow the existing rules." (Pulung interview, Cibeo) "Formal schools including the existing traditional violations are agricultural schools, namely ngoret, ngasek, nebang, etc. The reason is that they cannot live in satisfaction and it has become an adat provision that must be carried out. " (Interview with Aldi, Cibeo).

Based on the statements above, it is concluded that formal education (school) is still taboo, especially for the Baduy Dalam people who still adhere to traditional rules. As in the Baduy proverb "Lojor teu beunang is cut, Pondok teu thread is joined, Gede teu thread is pulled, Leutik teu beunang is added" meaning that it already exists and becomes the mandate of ancestors in the Baduy community life must be obeyed by the principle of life as it is in accordance with the rules that are in effect since their tribal civilization was born.

Meanwhile, to answer the formulation of the two problems namely how the Implementation of Parenting in Education in the Baduy Tribe Society is that the Baduy people have known the education system that they have applied since their tribal civilization was born with a special model or form, different from the model or form of education offered by the government Model / the form of education implemented in Baduy community life is through generations through oral methods and direct practice. The knowledge they usually get in the form of spells used to grow rice or in traditional ceremonies, craftmaking skills, and so forth. As for the learning process, the Baduy people get more knowledge from family, customs, and peers. The following will describe the role of the family environment, customs, and peers to education in the Baduy community.

The implications of the upbringing of parenting in education through the family environment In the Baduy community the role of the family in education is the most vital thing because in customary rules they say that formal education is something taboo. So in a family the child is prepared for his life to be able to live a social life, especially his understanding of the prevailing customs. Jaro Sami said that: "When children are less than ten years old traditional education is entrusted to 
parents, children begin to learn through practices such as learning agriculture, counting dates, etc. This opinion is very clear that when children are under the age of ten, parents who have the obligation to provide traditional education.

In the educational parenting patterns by the Baduy community, many children are applied by way of direct practice where children from an early age are invited to Huma (fields) to help their parents. As the researchers saw when it ended up in one of the huts belonging to the Inner Baduy community, namely the family of Aldi's father. There, Aldi's father invites all his children to come to the huma to help with his work and usually the family spends more time in Saung (where they live in the fields) rather than living in their home located in Cibeo village.

Impilakasi Application of fostering patterns in the Customary Environment (Customary Figures) The role of traditional institutions in children's education in the Baduy community, especially Baduy. for all sources of knowledge. So, the customary institution is tasked to supplement the deficiencies owned by parents as well as the community in general who need a school education institution to cover the deficiencies of parents both science and technology. Father Mursid explained the duties and functions of traditional institutions in the Baduy Dalam community, namely as follows:

"One of them is to remind adat, customary rules with a large number of visitors, with advances in traditional institutions or Jaro Tangtu (Jaro Sami) or leaders inviting their citizens to stick to traditional rules, respect these rules with values value because it seems as if we are together ...".
Customary

institutions

(traditional leaders) have a very important role, namely as a coach, supervisor, and decision maker for all actions in the life of the Baduy community. The purpose of traditional institutions is that the Baduy people live their lives not too freely and can maintain the continuity of the ancestral mandate so that young people are not left behind with increasingly difficult and unavoidable challenges. Impilakasi Implementation of foster patterns In the Baduy community learning through peers is something they usually do. The method they call the term Papagahan (teach each other). Through peers they also usually exchange knowledge such as learning to make skills and read and write. At this time especially the young generation of Inner Baduy, their curiosity over the development of the times is very high, where the authors pay attention in their spare time they usually gather in many stalls located in the Ciboleger terminal to watch television and if they are taking guests from outside they usually actively asking about what are the developments in the city.

\section{Discussion}

The results of the analysis of this study found that the educational parenting patterns by the Baduy people mainly follow what they inherit from their ancestors. It can be understood from the opinion that in the Baduy community, the most important education for them is education about traditional knowledge and how to apply parenting in education through three ways namely Implications for illuminating parenting in education through the Family environment, Impilakasi Application The pattern of fostering in the Customary Environment 
(Indigenous Figure) and the Impilacation of the Implementation of the Fostering Pattern in the Baduy community learns through peers. The information obtained from the study author documentation or literacy through a journal from Hasyim Asy'ari, Syaripullah, and Rudini Irawan about Education in the View of the Inner Baduy Society.

This study also includes analysis of different journals but in the same context. According to the journal by Rudini Irawan on Education in the Baduy community, the life of the Baduy community in a series of different and binding rules known as Pikukuh Karuhun, one area that is regulated in Pikukuh Karuhun is education, which in its implementation uses a special model or form that is different from education in general. This is their attempt to maintain the traditional mandate that has been passed down for generations. Where on the other hand caused the Baduy community to be left behind educationally as a result of the implementation of these rules they did not follow the formal education that the government had prepared.

\section{CONCLUSION}

Education in the Baduy tribe is education that inherits traditional knowledge. Baduy people stated that until now, especially for the Cibeo people, there has been no one had attending formal education; most of them are still using traditional methods to educate their children. The following is the statement of Ayah Aldi as a resident of the Cibeo village: "That for indigenous peoples it is not permitted to participate in formal education which is permitted only for family and traditional education. The application of parenting in education through three ways namely
Implications for the implementation of parenting in education through the family environment, implementation of fostering patterns in Indigenous Environments (Indigenous Leaders) and Implementation of Foster Patterns in the Baduy community through peer learning.

\section{REFERENCES}

[1] J. A. Scholte, "Globalisation, Governance and Corporate Citizenship," J. Corp. Citizsh., no. 1, pp. 15-23, 2001.

[2] D. K. Barker, "Globalization is a feminist issue," Lib. Econ. Fem. Perspect. Fam. Work. Glob., pp. 95-117, 2004.

[3] R. Robertson, Globalization: Social Theory and Global Culture. London: SAGE Publications, 1992.

[4] M. R. Dove, "Indigenous People and Environmental Politics," Annu. Rev. Anthropol., vol. 35, no. 1, pp. 191-208, 2006, doi: 10.1146/annurev.anthro.35.08170 5.123235 .

[5] Y. Octavitri, "Persepsi Masyarakat Kabupaten Lebak Provinsi Banten terhadap Upacara Seba Suku Baduy," SulukIndo, vol. 2, no. 2, pp. 228-243, 2013.

[6] aan Hasanah, "Pengembangan Karakter pada masyarakat Minoritas," Analisis, vol. XII, pp. 209-229, 2012.

[7] I. Suryani, "MENGGALI KEINDAHAN ALAM DAN KEARIFAN LOKAL SUKU BADUY (Studi Kasus Pada Acara Feature Dokumenter 'Indonesia Bagus' di Stasiun Televisi NET.TV)," Musãwa J. Stud. Gend. dan Islam, vol. 13 , no. 2, p. 179, 2014, doi: 10.14421/musawa.2014.132.179194.

[8] S. S. Suparmini and D. R. S. 
Sumunar, "PELESTARIAN LINGKUNGAN MASYARAKAT BADUY BERBASIS KEARIFAN LOKAL," 2013.

[9] S. Ngamanken, "Fenomena Keterlantaran Suku Baduy di Pulau Jawa," Humaniora, vol. 4, no. 2, p. 1064, 2013, doi: 10.21512/humaniora.v4i2.3547.

[10] B. Setiani, "Fungsi Dan Peran Wanita Dalam Masyarakat," Lex Jurnalica, vol. 3, no. 3, pp. 153-167, 2006.

[11] A. Kurnia, A. Sihabudin, and F. Yustianti, Saatnya Baduy bicara. Bandung: Bumi Aksara, 2010.

[12] S. Gunarsa, Psikologis Praktis. Jakarta: Gunung Mulia, 2000.

[13] R. Kartika, "Pola Pengasuhan Anak Pada Orang Tua Tuna Netra (Studi Kasus Klinik Pijat Tuna Netra Barokah)," J. Pendidik. Ilmu Sos., vol. 27, no. 2, p. 156, 2018, doi: 10.17509/jpis.v27i2.14095.

[14] P. Gracia and J. Ghysels, "Educational inequalities in parental care time: Cross-national evidence from Belgium, Denmark, Spain, and the United Kingdom," Soc. Sci. Res., vol. 63, pp. 166-180, 2017, doi: 10.1016/j.ssresearch.2016.09.016.

[15] Casmini, Emotional parenting: Dasar-dasar pengasuhan kecerdasan emosi. Yogyakarta: Pilar Media, 2007.

[16] M. Thoha, Perilaku Organisasi. Jakarta: Raja Grafindo Persada, 1996.

[17] M. K. Khon, Class and Conformity: A Study in Values. Chicago: The University of Chicago Press, 1977.

[18] B. Monna and A. H. Gauthier, "A Review of the Literature on the Social and Economic Determinants of Parental Time," J. Fam. Econ. Issues, vol. 29, no. 4, pp. 634-653, Dec. 2008, doi: 10.1007/s10834-008-9121-z.

[19] R. M. Pasaribu, D. Hastuti, and Alfiasari, "KELUARGA BERISIKO TERHADAP PENURUNAN KARAKTER REMAJA Permissive Parenting Style and Lack of Values Socialization in Family are The Risk Factors for Decreasing of Adolescents , Character Abstract," vol. 6, no. 3, pp. 163171, 2013.

[20] I. Nurlin, Hukum dan Sanksi Adat Perspektif Pembaharuan Hukum Pidana. Malang: Setara Press.

[21] M. Liputo, Empat Aspek Adat Daerah Gorontalo. Gorontalo: Pemda Kabupaten Daerah Tingkat II, 1985.

[22] J. Garna, "Tangtu Telu Jaro Tujuh: Kajian Struktural Masyarakat Baduy di Banten Selatan Jawa Barat Indonesia," University Kebangsaan Malaysia, Bangi, 1987.

[23] S. N. Sukmadinata, Metode Penelitia. Bandung: PT Remaja Rosdakarya, 2005.

[24] M. Rahardjo, Antara Konsep Proporsi, Teori, Variabel dan Hipotesis Penelitian. Yogyakarta: Gadjah Mada University Press, 2018.

[25] B. Bungin, Metodologi Penelitian Kuantitatif: Komunikasi, Ekonomi, dan Kebijakan Publik serta Ilmuilmu Sosial Lainnya, 2nd ed. Jakarta: Kencana, 2014.

[26] Z. A. Agustina, Nf. Suharmiyati, and $M$. Ipa, "Penggunaan Kecombrang (Etlingera elatior) sebagai Alternatif Pengganti Sabun dalam Perilaku Hidup Bersih dan Sehat Suku Baduy," Media Penelit. dan Pengemb. Kesehat., vol. 26, no. 4, 2016, doi: 10.22435/mpk.v26i4.5179.235-242. 